\title{
Systemic Risk in Indian Banking: Measurement and Impact of COVID-19
}

\author{
Kalpakam $G^{\star}$, Krina TRIVEDI ${ }^{\star \star}$
}

\begin{tabular}{l}
\hline \multicolumn{1}{c}{ A R T I C L E I N F O } \\
\hline Article history: \\
Accepted April 2021 \\
Available online May 2021 \\
\hline JEL Classification \\
D81, E58, C62, G32 \\
Keywords: \\
Risks in Banking, SRISK, Economic \\
Stability
\end{tabular}

Stability

\begin{abstract}
A B S T R A C T
This study examines the systemic risk in the Indian banking system using two models. The systemic risk cube explains the importance of measuring systemic risk in a scenario like contagion and systemic risk measurement index SRISK as proposed by NYU stern. Measurement of SRISK is done for two time-periods: before COVID-19 i.e. February 2020 and after COVID-19 i.e. February 2021. The findings show that the COVID-19 pandemic has not shown increase in SRISK considerably unlike 2009 crisis when the SRISK increased considerably, causing an economic downturn. The banking system remains a vital part for economic stability and studying the financial system to scale its impact on the economy during extreme events like in a pandemic remains an unflinching necessity of the time.
\end{abstract}

(C) 2021 EAI. All rights reserved.

\section{Introduction}

Systemic risks are the non-conventional risks associated with the collapse or failure of a system. Systemic implies within the boundaries of a system, which is a complex one comprised of interrelated procedures and mechanisms working together. As per the above definition, the system under consideration in this paper is the financial banking system. Hence systemic risk results in a domino effect eventually leading to an economic slump due to collapse of the financial system.

In this paper, we look at the systemically important banks (SIBs), the failure of which would cause the economy and entire financial system to collapse due to their inter-connected businesses and intermediaries. This cascading effect can spread across the whole financial system, in turn causing the economy to collapse. The strong interconnect between elements makes defining the systemic risks hard and measuring the impact harder.

The past financial crisis of the US in 2008-09 and European crises in 2010-11 have proved that it is paramount to take note of factors in the systemic risk to financial institutions arising from other parts of the world. Initially the Indian banking system was relatively unaffected by the crises mentioned above, but it was indirectly affected due to the presence of foreign banks in India. This has proved that monitoring of systemic risk is essential to avoid potential system failure.

The COVID-19 pandemic in 2020 is yet another existing example of triggering a systemic risk that might cause the economy to collapse. It is important to note that in India, the government has rolled out fiscal packages to boost economic growth and help the borrowers to pay their debt. However, it is also vital to consider the stress it puts on the banks and whether the banks will withstand this strain.

The Indian banking system includes both public sector banks and banks in the private sector. Public sector banks are owned and controlled by the government and are subjected to political interference and constraints. At the same time, private sector banks are said to be more stable because the shares are not owned by Government and therefore better managed without political interference. This paper measures the systemic risks in both the public and private sector banks pre and post COVID-19 contagion.

Reserve Bank of India (RBI) conducts a systemic risk survey (SRS) to capture experts' perceptions, including market participants, on the significant risks faced by the financial system. SIBs are perceived as banks that are 'Too Big to Fail'. This gives rise to an expectation of government to support these banks in times of distress. Due to which the banks enjoy an undue advantage in the funding markets. However, this support increases the risk-taking behavior and reduces discipline thus increasing the probability of distress in the future. Hence to avoid such slippages and reduce the moral hazard posed by them, the SIBs are subjected to various additional policy measures.

According to the Basel III norms, a framework was created to deal with the Domestically Systemically Important Banks (D-SIBs). In a D-SIB framework, the national authorities carry out an 
assessment to assess the effect on the local economy and banks and thereby take action to restrict the negative impact emanating from systemic forces outside and provide necessary stimulus. RBI releases a list of these D-SIBs based on the data collected from the banks and notifies in the press release the systemically important banks. A comparison of the research of systemically important banks pre-COVID and post-COVID is made with RBIs list later in this paper. This will help us draw further insights into the current situation of the economy.

\section{Literature Review}

Many approaches are proposed for measuring systemic risk in the literature (Adrian and Brunnermeier, 2008; Acharya et al., 2010a, 2010b; Acharya and Steffan, 2012; Moore and Zhou, 2014; Van Oordt and Zhou, 2015). The measurement of systemic risk can expose the vulnerability of a system to cause a failure. There is extensive ongoing research and debate to find an unrivalled systemic risk measure. We have used two popular models to understand it.

The systemic risk cube was first introduced in the 2009 Financial Stability Review Report by the European Central Bank. The cube helps to visualize the systemic risk conceptually. It has three axes viz, triggers, origins, and impacts. Triggers are the starting point of the crisis which could be exogenous shocks or endogenous. Exogenous shocks are the events outside the system under consideration and endogenous are the shocks which are within the system. Financial crisis of 2009 was an endogenous shock caused due to the collapse of banking system. The second axis of origin indicates that the trigger can be limited and distinguished or widespread and systemic. The third and final axis of impact indicated the influence of the shock will either affect a single portion of the system or will affect the entire system.

Another measure is the SRISK index as proposed by Brownlees and Engle $(2012,2017)$ and Acharya et al. (2012) as an estimate of the expected capital shortage of a bank during a market meltdown. Hattori et al. (2014) sited that certain types of trigger events based on past patterns of failure are used for measuring systemic risk which is indirectly a form of scenario analysis. He however raised concerns that this may not be a robust indicator against future failures which are unprecedented. Also, they argued that most market-based estimates of systemic risk might overestimate the importance of short-term changes. It was suggested that for a broader range of failure sources, the macro stress testing scenarios needed to be merged with different risk measures.

In the case of contagion like COVID-19, the RBI Governor Shantikanta Das has sited that 'once in a lifetime' economic events are becoming 'once in a decade' events. Using the standard VaR and CoVaR does not effectively measure these extreme tail events that happen once or twice a decade.

V Acharya, Pederson, Phillipon and Richardson (2010) have used extreme value theory and define Marginal Expected Shortfall (MES) where they link an extreme tail event and moderately bad event. When the equity value in comparison to its debts reduces to a very small fraction in a financial firm, the entity cannot function while in a normal situation there is a likelihood of acquisition or even raise fresh capital. The problem could be compounded when the firm is also facing systemic financial constraints. Government of that country is faced with a dilemma to bail out the bank with taxpayers' money if there is no other option, otherwise a capital shortage of the financial entity will affect the economy as a whole.

Verma et.al (2019) use Tail-Event-Driven Networks (TENET) risk model and observe that SBI and HDFC are Domestic Systemically Important Banks along with a few other banks. Their findings reveal that Government owned banks are more vulnerable as compared to private owned banks. Six factors cause it, viz. banking panics - when depositors withdraw more money than they need for consumption; banking crises due to falling asset prices; contagion; financial architecture; foreign exchange mismatches in the banking system and due to uncharted waters - such as the referendum on the 'Brexit' (Allen, Goldstein and Jagtiani 2018)

\section{Research Methodology}

The objective is to measure the systemic risks and gauge the impact of COVID-19 by observing the change in the systemic risk measured. For this study, 32 publicly traded Indian Banks are taken into consideration, including 12 public sector and 20 private sector banks. The data for analysis was collected from NSE, yahoo finance and money control. Calculation of beta used in LRMES for both the periods was manually calculated using daily stock returns for one-year tenure in each case. The market capitalization calculated is as of February 29 2020, for pre-COVID analysis and February 28 2021, for post-COVID analysis. In order the get the debt values of the banks for 2021, forecasting was done based on the average year on year growth of the past five years.

The calculation of systemic risk is in two steps. First is estimating the fractional loss in equity while in a crisis. The crisis under this pretext looks for a considerable aggregate market decline over a six-month period. This is called Long-Run Marginal Expected Shortfall or LRMES. LRMES is calculated using the below formula: 
where $d$ is the crisis threshold for the market index decline, and beta is the responsiveness of a stock's price to changes in the overall stock market. For calculations, the crisis threshold is taken as $40 \%$ for this study which is also the default value considered.

This measure is the mean of the returns of equity in the crisis scenario. The measure contains the volatility of the firm and its correlation with the market, as well as its performance in extremes. The list of banks under consideration in the study are mentioned in Table 1 below.

Table 1. List of Banks

\begin{tabular}{|l|l|}
\hline \multicolumn{1}{|c|}{ Public Sector } & \multicolumn{1}{c|}{ Private Sector } \\
\hline PNB & ICICI Bank \\
\hline Bank of Baroda & Kotak Mahindra \\
\hline Canara Bank & Axis Bank \\
\hline Union Bank & IndusInd Bank \\
\hline Bank of India & Bandhan Bank \\
\hline IOB & Yes Bank \\
\hline Indian Bank & AU Small Finance \\
\hline UCO Bank & IDBI Bank \\
\hline Bank of Maharashtra & IDFC First Bank \\
\hline Central Bank & Federal Bank \\
\hline Punjab \& Sind & RBL Bank \\
\hline & City Union Bank \\
\hline & Equitas Bank \\
\hline & Karur Vysya \\
\hline & DCB Bank \\
\hline & JK Bank \\
\hline & Karnataka Bank \\
\hline & South Ind Bk \\
\hline & Dhanlaxmi Bank \\
\hline
\end{tabular}

Secondly, the current equity market value is combined with the shortfall calculated during the crisis and subtracted from the outstanding debt of the firm to calculate the capital required during a crisis. The method describes it as SRISK (Systemic Risk); symbolically, it can be defined as

$$
\text { SRISK }_{\mathrm{i}, \mathrm{t}}=\mathrm{E}_{\mathrm{t}-1} \text { (Capital Shortfall } \mid \mathrm{C} \text { Crisis) }
$$

Equation 2

When the capital shortfall is very high, these firms end up winding up their business and also precipitate more to the crisis. Capital shortfall (SRISK) is computed as

$$
\text { SRISK=k } \times \text { DEBT }-(1-k) \times \text { EQUITY } \times(1-L R M E S)
$$

\section{Equation 3}

where $\mathrm{k}$ is the capital requirement, DEBT is the book value of debt calculated as book value of assets less book value of equity, EQUITY is the current market capitalization of this firm and LRMES is the long run marginal expected shortfall.

\section{Findings}

To gauge the impact of COVID-19 by measuring SRISK for both public sector and private sector banks, the data was analyzed for two time periods. Before COVID-19 impact of February 2020 and post COVID-19 impact for February 2021. The calculated SRISK is shown below in Table 2 for public sector banks and Table 3 for private sector banks.

Table 2. SRISK values for public sector banks

\begin{tabular}{|l|r|r|}
\hline \multicolumn{1}{|c|}{ Name } & \multicolumn{1}{|c|}{ Post COVID } & \multicolumn{1}{c|}{ Pre COVID } \\
\hline & \multicolumn{1}{c|}{ SRISK21 } & \multicolumn{1}{c|}{ SRISK 20 } \\
\hline SBI & $1,43,607.34$ & $1,87,877.85$ \\
\hline PNB & $40,725.98$ & $50,401.64$ \\
\hline Bank of Baroda & $86,586.73$ & $75,913.31$ \\
\hline Canara Bank & $49,324.40$ & $54,203.86$ \\
\hline
\end{tabular}




\begin{tabular}{|l|r|r|}
\hline \multicolumn{1}{|c|}{ Name } & \multicolumn{1}{c|}{ Post COVID } & \multicolumn{1}{c|}{ Pre COVID } \\
\hline & \multicolumn{1}{c|}{ SRISK21 } & \multicolumn{1}{c|}{ SRISK 20 } \\
\hline Union Bank & $34,123.52$ & $39,367.65$ \\
\hline Bank of India & $41,034.66$ & $45,706.35$ \\
\hline IOB & $6,661.64$ & $11,083.23$ \\
\hline Indian Bank & $18,690.79$ & $22,902.46$ \\
\hline UCO Bank & $8,515.78$ & $10,584.61$ \\
\hline Bank of Maharashtra & $6,219.80$ & $9,940.69$ \\
\hline Central Bank & $24,563.56$ & $23,856.66$ \\
\hline Punjab \& Sind & $7,775.60$ & $7,782.69$ \\
\hline
\end{tabular}

Table 3. SRISK values for Private sector banks

\begin{tabular}{|l|r|r|}
\hline \multicolumn{1}{|c|}{ Name } & Post-COVID & \multicolumn{1}{c|}{ Pre COVID } \\
\hline HDFC Bank & $-4,68,985.85$ & $-3,42,936.79$ \\
\hline ICICI Bank & $-1,79,829.55$ & $-1,15,947.39$ \\
\hline Kotak Mahindra & $-2,40,031.58$ & $-1,98,097.85$ \\
\hline Axis Bank & $-56,616.70$ & $-59,073.82$ \\
\hline IndusInd Bank & $-18,391.44$ & $-23,848.77$ \\
\hline Bandhan Bank & $-24,328.69$ & $-35,395.07$ \\
\hline Yes Bank & $-14,322.42$ & $-4,338.89$ \\
\hline AU Small Finance & $-19,448.01$ & $-24,804.31$ \\
\hline IDBI Bank & $-1,120.11$ & $-2,882.99$ \\
\hline IDFC First Bank & $-6,372.31$ & -11.52 \\
\hline Federal Bank & $7,064.71$ & $3,924.26$ \\
\hline RBL Bank & $-1,257.20$ & $-1,411.70$ \\
\hline City Union Bank & $-4,321.51$ & $-8,724.06$ \\
\hline Equitas Bank & $-1,820.33$ & $-5,693.22$ \\
\hline Karur Vysya & $2,448.80$ & $3,102.12$ \\
\hline DCB Bank & $1,228.12$ & 553.12 \\
\hline JK Bank & $8,420.01$ & $8,184.82$ \\
\hline Karnataka Bank & $6,144.08$ & $5,606.50$ \\
\hline South Ind Bk & $8,056.70$ & $7,056.60$ \\
\hline Dhanlaxmi Bank & 754.04 & 760.00 \\
\hline
\end{tabular}

The public sector banks have a positive SRISK, while private sector banks have a negative SRISK barring few banks as can be observed from Table 3 above. It can be observed that there is not a vast difference in the systemic risks post-COVID even though the debt of the banks is expected to increase. This is due to a massive boost in the Indian Equity markets, increasing the market capitalization of the bank.

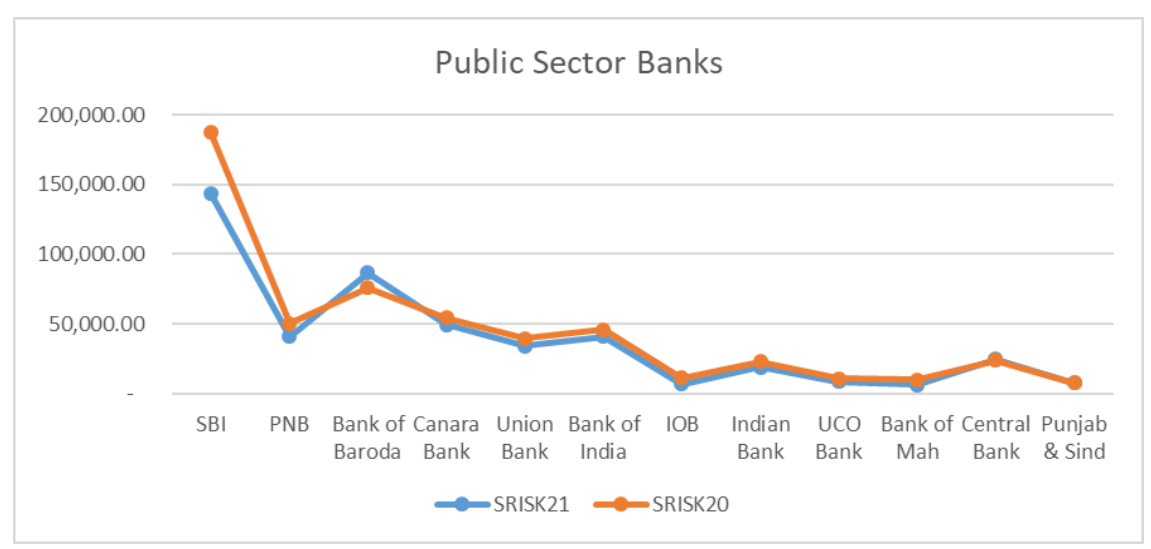

Figure 1. SRISK pre and post COVID of Public Sector Banks 


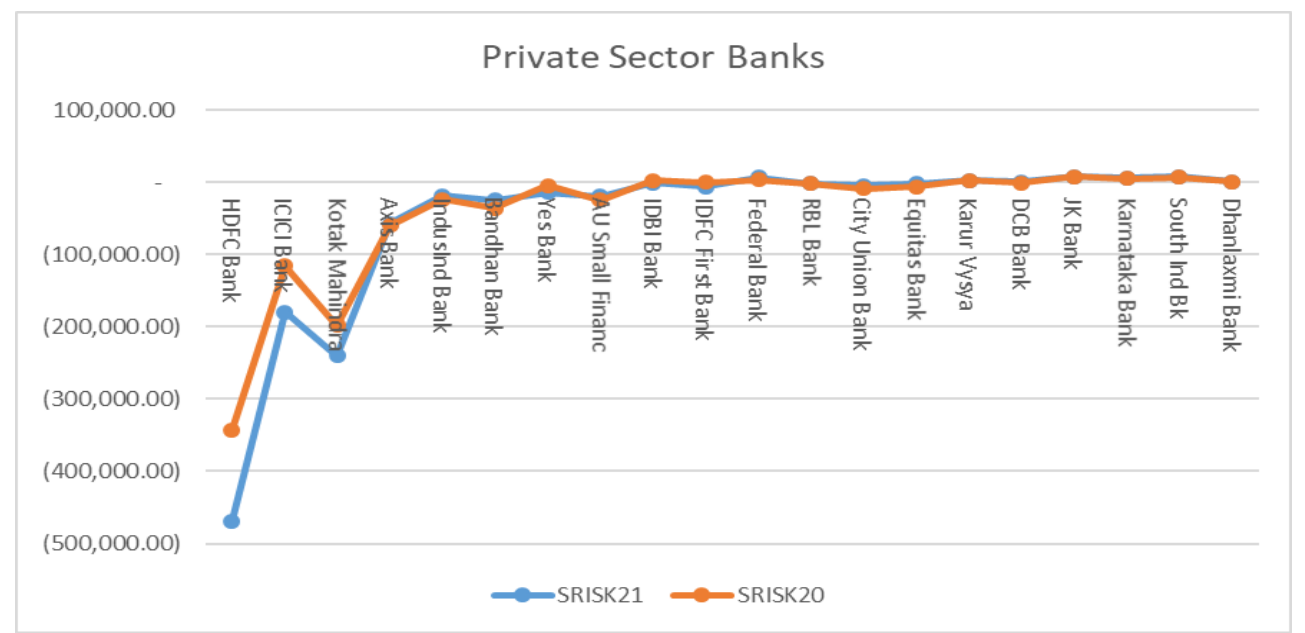

Figure 2. SRISK pre and post COVID of Private Sector Banks

\subsection{Comparison with NYU stern VLAB}

From the below image from VLAB, we can see that the systemic risk for the Indian Banking system as computed by NYU is decreasing post-COVID-19 in February 2021. This can also be observed in Figure 2, where the public sector banks SRISK has reduced post-COVID-19. The private sector banks, however, seem to have an increased SRISK if the absolute values are taken into consideration.

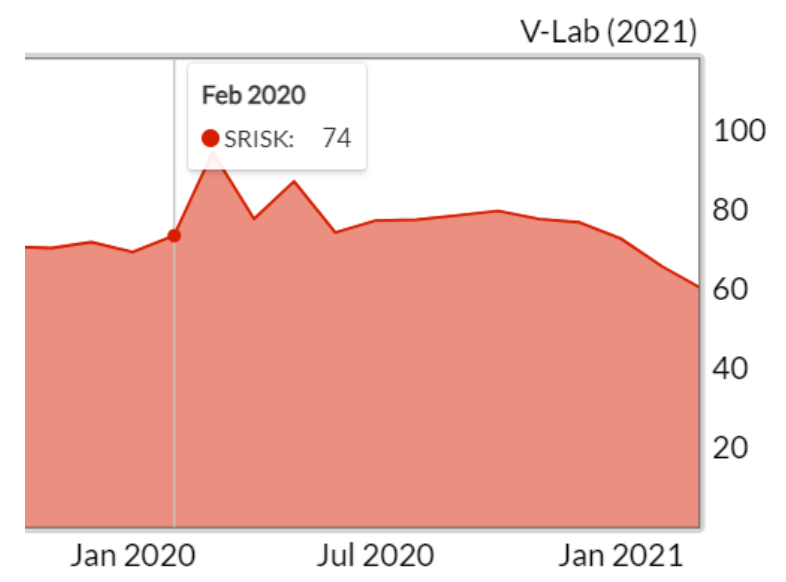

Figure 3. SRISK\% measure for Feb 2020 by NYU VLAB

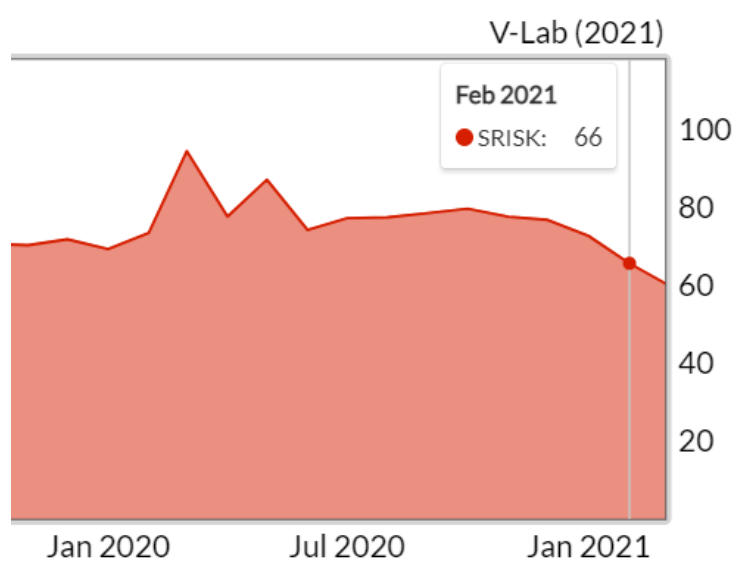

Figure 4. SRISK\% measure for Feb 2021 by NYU VLAB

\subsection{Comparison with RBI Systemic Risk Survey (SRS) report of January 2021:}

The systemically important banks in the public sector are SBI, Bank of Baroda, Canara Bank, shown in Figure 2. For private sector banks, figure 3 shows that HDFC Bank, Kotak Mahindra and ICICI Bank are 
systemically significant. Hence these banks are too big to fail, but if they fail, it can lead to an economic downturn. As stated earlier, the RBI conducts SRS survey and releases a list of banks which are systemically important for the Indian economy.

From the calculated SRISK values, for the private banks, apart from HDFC bank and ICICI bank; Kotak Mahindra bank should also be considered as a D-SIB. The value for SRISK signifies that organizations with huge capital shortfall are not only the biggest losers during a crisis but also pose a higher risk to the system. This makes Kotak Mahindra an important consideration for the list of banks which are too big to fail for the economy and poses a threat for systemic failure.

\section{Conclusion}

The study contributes to the literature by analyzing the impact of an ongoing contagion of COVID-19 on the Indian banking system. Earlier studies and the literature consist of the need for analyzing systemic risk due to the financial crisis of 2009. However, we can now observe the systemic risk associated with the financial systems when a pandemic occurs. These are extreme events, and a comparative study of both endogenous (Financial crisis of 2009) and exogenous (COVID-19) events show that it does not have a similar impact on the riskiness of the financial institutions. While on the one hand, in 2009, the SRISK increased considerably, causing an economic downturn, the COVID-19 pandemic has not shown a similar alert.

It can be concluded that the impact of COVID-19 has been minimized on the systemic risk of the Indian Banking sector due to the equal boost in the Indian equity markets leading to an increase in the market capitalization of the banks. As a part of RBI SRS, it is our suggestion to include Kotak Mahindra bank apart from the existing SBI, HDFC Bank and ICICI bank as a systemically important bank (SIBs).

Reserve Bank of India Governor has urged banks to augment their stress testing framework with various scenarios and watch out for any early warning signals and take corrective action on their own proactively, particularly the SIB banks where their strength lies in building their capital base and also create sufficient provisions in the event of any defaults. RBI at the apex will provide liquidity in the system and maintain flow of credit in the economy

The study can further be extended to non-banking financial institutions to understand its impact on the Indian economy. Also, there is a constant debate on the 'fat-tail normal distribution' assumption of economic events, i.e. economic events follow a bell-shaped or normal distribution. This study can be extended to a non-normal distribution expected to simulate a stress scenario close to what is being played out during the COVID crisis.

\section{References}

1. Acharya, V.V., Brownlees, C., Engle, R., Farazmand, F., and Richardson, M. (2010), “Measuring Systemic Risk," in Regulating Wall Street: The Dodd-Frank Act and the New Architecture of Global Finance, edited by Acharya, V.V., Cooley, T., Richardson, M., and Walter, I., John Wiley \& Sons.

2. Acharya, V.V., Engle, R.F., and Richardson, M. (2012), "Capital Shortfall: A new approach to ranking and regulating systemic risks," Presented at the American Economic Association Meeting held at Chicago, Illinois, USA on Jan 7, 2012.

3. Acharya, V.V., Pedersen, L., Philippon, T., and Richardson, M. (2010), "Measuring Systemic Risk," NYU Stern Working Paper.

4. Acharya, V.V. and Steffen, S. (2012), "Analyzing Systemic Risk of the European Banking Sector," NYU Stern Working Paper in Handbook on Systemic Risk, edt. J.-P-Fouque and J. Langsam. Cambridge University Press

5. Acemoglu D., Ozdaglar A., and Tahbaz-Salehi. (2015), American Economic Review, 105(2): 564-608

6. Adrian, T. and Brunnermeier, M.K. (2008), “CoVaR," Federal Reserve Bank of New York Staff Report No. 348.

7. Allen, F., Goldstein, I., \& Jagtiani, J. (2018). The Interplay between Financial Regulations, Resilience, and Growth CEPR Discussion Paper No. DP12861

8. Allen I., and Douglas G. (2000a), "Bubbles and Crises," Economic Journal, 110(460), 236-255

9. Allen F., and Douglas G. (2000b), "Financial Contagion,"Journal of Political Economy, 108(1), 1-33

10. Anghelache, G.-V. and Oanea, D.-C. (2016), "Romanian Commercial Banks' Systemic Risk and Its Determinants: A CoVaR Approach," International Journal of Academic Research in Accounting, Finance and Management Sciences 6(3), 96-109.

11. Boot, A.W.A. and Ratnovski, L. (2012), "Banking and Trading," International Monetary Fund Working Paper No. 12/238.

12. Brewer III, Elijah, and Julapa J. (2013) "How Much Did Banks Pay to Become Too-Big-to-Fail and to Become Systemically Important?" Journal of Financial Services Research, 43(1), 1-35

13. Demirer, M., Diebold, F.X., Liu, L., Yilmaz, K. (2018) "Estimating global bank network connectedness" J. Appl. Econometrics 33 (1), 1-15.

14. Economic Survey, 2016-2017. Ministry of Finance, Govt. of India, New Delhi. FSR, 2015. "Report on Trend and Progress of Banking in India 2014-15 and Financial Stability Report 2015" Reserve Bank of India (RBI), Mumbai, India

15. Financial Stability Review Report December 2009: Financial Stability Review December 2009 (europa.eu) accessed on December 03 2020

16. Frameworkfor DSIBs: https://rbidocs.rbi.org.in/rdocs/Content/PDFs/FDSIBF220714.pdf accessed on 28th November 2020

17. Federal Reserve Bank of Minneapolis. "Ending Too Big to Fail," final proposal dated January 10, 2018

18. Freixas X., Bruno Maria Parigi, and Jean-Charles Rochet. (2000), "Systemic Risk, Interbank Relations and Liquidity Provision by the Central Bank," Journal of Money, Credit and Banking, 32(3)

19. Härdle, W.K., Wang, W., Yu, L. (2016) "TENET: Tail-Event driven NETwork risk". J. Econometrics 499-513

20. Hattori, A., Kikuchi, K., Niwa, F., and Uchida, Y. (2014), "A Survey of Systemic Risk Measures: Methodology and Application to the Japanese Market," IMES Discussion Paper Series, No. 2014-E-3

21. Kritzman, M., Li, Y., Page, S., Rigobon, R. (2011) "Principal components as a measure of systemic risk." J. Portfolio Manag. 37 (4), 112126.

22. NYU Stern VLAB: V-Lab: U.S. Financials Dynamic MES Systemic Risk Analysis (nyu.edu) accessed on January 272021, March 012021

23. Patro, D.K., Qi, M., Sun, X. (2013) “A simple indicator of systemic risk." J. Financ. Stab. 9 (1), 105-116.

24. RBI press release: Reserve Bank of India - Press Releases (rbi.org.in) accessed on March 012021 
25. Sundaresan, Suresh and Zhenyu Wang (2015), "On the Design of Contingent Capital with a Market Trigger,"Journal of Finance

26. Verma, R., Ahmad, W., Uddin, G. S., \& Bekiros, S. (2019). Analysing the systemic risk of Indian banks. Economics letters, 176, 103-108.

27. Wang, G.-J., Jiang, Z.-Q., Lin, M., Xie, C., Stanley, H.E. (2018a) "Interconnectedness and systemic risk of China's financial institutions." Emerg. Markets Rev. 35, 1-18.

28. Wang, G.J., Xie, C., He, K., Stanley, H.E. (2017) "Extreme risk spill over network: application to financial institutions". Quant. Finance 17 (9), 1417-1433.

29. Wang, G.J., Xie, C., Zhao, L., Jiang, Z.Q. (2018b) "Volatility connectedness in the Chinese banking system: do state-owned commercial banks contribute more?" J. Int. Finance Markets Institute Money 57, 205-230.

30. Zhou, C. (2010) “Are banks too big to fail? Measuring systemic importance of financial institutions." Int. J. Central Bank. 6 (4), 205-250

31. https://www.business-standard.com/article/news-cm/maintaining-health-of-banking-sector-remains-policy-priority-says-rbigovernor-121032600907 1.html

SRISK calculation of Public Sector Banks

Appendix A

\begin{tabular}{|l|l|l|l|r|}
\hline Feb 2021 Public Sector & $\begin{array}{l}\text { Market Cap (Rs. } \\
\text { Cr) }\end{array}$ & Debt & LRMES & SRISK \\
\hline SBI & 349889.4 & 4306530.54 & 0.23373 & $1,43,607.34$ \\
\hline PNB & 41334.46 & 807959.89 & 0.14952 & $40,725.98$ \\
\hline Bank of Baroda & 36756.61 & 1259120.44 & 0.20074 & $86,586.73$ \\
\hline Canara Bank & 26446.62 & 750693.24 & 0.24218 & $49,324.40$ \\
\hline Union Bank & 21559.03 & 563313.84 & 0.15516 & $34,123.52$ \\
\hline Bank of India & 19923.69 & 627271.26 & 0.14952 & $41,034.66$ \\
\hline IOB & 18672.42 & 241501.64 & 0.11290 & $6,661.64$ \\
\hline Indian Bank & 13857.33 & 319911.10 & 0.19896 & $18,690.79$ \\
\hline UCO Bank & 12883.92 & 213300.72 & 0.08897 & $8,515.78$ \\
\hline Bank of Maharashtra & 10109.2 & 159783.96 & 0.11290 & $6,219.80$ \\
\hline Central Bank & 8419.68 & 349291.64 & 0.10301 & $24,563.56$ \\
\hline Punjab \& Sind & 997.6 & 95012.45 & 0.14573 & $7,775.60$ \\
\hline
\end{tabular}

\section{Feb 2020 Public Sector}

\begin{tabular}{|l|l|l|l|c|}
\hline Company Name & Market Cap (Rs. Cr.) & Debt & LRMES & SRISK \\
\hline SBI & 270415.7295 & 3946432.22 & 0.32013 & $1,87,877.85$ \\
\hline PNB & 30352.7341 & 768308.43 & 0.32131 & $50,401.64$ \\
\hline Bank of Baroda & 35254.92444 & 1086059.30 & 0.31949 & $75,913.31$ \\
\hline Canara Bank & 14804.45294 & 700234.32 & 0.34552 & $54,203.86$ \\
\hline Union Bank & 12715.7729 & 521519.66 & 0.34587 & $39,367.65$ \\
\hline Bank of India & 16728.69337 & 617945.70 & 0.34910 & $45,706.35$ \\
\hline IOB & 14300.17984 & 244571.85 & 0.16022 & $11,083.23$ \\
\hline Indian Bank & 4508.168478 & 287373.38 & 0.27820 & $22,902.46$ \\
\hline UCO Bank & 12249.15067 & 216698.52 & 0.19992 & $10,584.61$ \\
\hline Bank of Maharashtra & 6086.194219 & 158108.35 & 0.22558 & $9,940.69$ \\
\hline Central Bank & 8907.229849 & 335800.94 & 0.21469 & $23,856.66$ \\
\hline Punjab \& Sind & 1069.105971 & 94907.41 & 0.21987 & $7,782.69$ \\
\hline
\end{tabular}

\section{SRISK calculation of Private Sector Banks}

Appendix B

\begin{tabular}{|l|l|l|l|l|}
\hline \multicolumn{5}{|l|}{ Feb 2021 Pvt Sector } \\
\hline Company Name & $\begin{array}{l}\text { Market Cap (Rs. } \\
\text { Cr.) }\end{array}$ & Debt (Rs. Cr.) & LRMES & SRISK \\
\hline HDFC Bank & 872380.74 & 1699753.337 & 0.216539 & $-4,68,985.85$ \\
\hline ICICI Bank & 436892.02 & 1197147.812 & 0.276677 & $-1,79,829.55$ \\
\hline Kotak Mahindra & 387015.98 & 398793.076 & 0.216539 & $-2,40,031.58$ \\
\hline Axis Bank & 224927.67 & 969191.1259 & 0.29724 & $-56,616.70$ \\
\hline
\end{tabular}




\begin{tabular}{|l|l|l|l|c|}
\hline IndusInd Bank & 77410.76 & 333638.6916 & 0.312659 & $-18,391.44$ \\
\hline Bandhan Bank & 53362.82 & 113090.1916 & 0.289401 & $-24,328.69$ \\
\hline Yes Bank & 41090.05 & 275177.2414 & -0.04537 & $-14,322.42$ \\
\hline AU Small Finance & 34052.68 & 65278.45525 & 0.182809 & $-19,448.01$ \\
\hline IDBI Bank & 31880.87 & 249229.3294 & 0.18823 & $-1,120.11$ \\
\hline IDFC First Bank & 28648.2 & 150666.8243 & 0.235426 & $-6,372.31$ \\
\hline Federal Bank & 16536.61 & 201059.5801 & 0.266984 & $7,064.71$ \\
\hline RBL Bank & 14531.86 & 95178.67742 & 0.257162 & $-1,257.20$ \\
\hline City Union Bank & 12183.62 & 49790.99927 & 0.20604 & $-4,321.51$ \\
\hline Equitas Bank & 5179.04 & 22001.14183 & 0.193614 & $-1,820.33$ \\
\hline Karur Vysya & 4344.31 & 64073.14421 & 0.160762 & $2,448.80$ \\
\hline DCB Bank & 3386.06 & 41935.8969 & 0.173694 & $1,228.12$ \\
\hline JK Bank & 2122.52 & 111289.0178 & 0.173694 & $8,420.01$ \\
\hline Karnataka Bank & 2015.99 & 85110.87564 & 0.173694 & $6,144.08$ \\
\hline South Ind Bk & 1491.21 & 102116.6872 & 0.164477 & $8,056.70$ \\
\hline Dhanlaxmi Bank & 346.37 & 11317.38438 & 0.160762 & 754.04 \\
\hline
\end{tabular}

\begin{tabular}{|l|l|l|l|l|}
\hline Feb 2020 Pvt Sector & $\begin{array}{l}\text { Market Cap } \\
\text { Company Name }\end{array}$ & Debt (Rs. Cr.) & LRMES & SRISK \\
\hline HDFC Bank & 645739.24 & 1404471.72 & 0.201292 & $-3,42,936.79$ \\
\hline ICICI Bank & 321858.25 & 1108845.92 & 0.2634 & $-1,15,947.39$ \\
\hline Kotak Mahindra & 309979.16 & 344526.92 & 0.187803 & $-1,98,097.85$ \\
\hline Axis Bank & 196755.60 & 841531.39 & 0.247063 & $-59,073.82$ \\
\hline IndusInd Bank & 76569.82 & 272480.57 & 0.305783 & $-23,848.77$ \\
\hline Bandhan Bank & 61753.00 & 76522.34 & 0.247586 & $-35,395.07$ \\
\hline Yes Bank & 43424.63 & 236137.2 & 0.35239 & $-4,338.89$ \\
\hline AU Small Finance & 35366.50 & 37766.2599 & 0.123673 & $-24,804.31$ \\
\hline IDBI Bank & 31764.62 & 265877.61 & 0.271911 & $2,882.99$ \\
\hline IDFC First Bank & 17700.44 & 133755.03 & 0.25193 & -11.52 \\
\hline Federal Bank & 17116.99 & 168530.97 & 0.278172 & $3,924.26$ \\
\hline RBL Bank & 14668.87 & 78418.53 & 0.365527 & $-1,411.70$ \\
\hline City Union Bank & 15810.93 & 44437.46 & 0.115688 & $-8,724.06$ \\
\hline Equitas Bank & 10808.23 & 16570.4 & 0.269527 & $-5,693.22$ \\
\hline Karur Vysya & 3341.16 & 61677.9 & 0.194563 & $3,102.12$ \\
\hline DCB Bank & 5022.52 & 35082.99 & 0.188143 & -553.12 \\
\hline JK Bank & 1409.07 & 102478.62 & 0.190282 & $8,184.82$ \\
\hline Karnataka Bank & 1966.96 & 77343.04 & 0.243338 & $5,606.50$ \\
\hline South Ind Bk & 1673.99 & 91555.55 & 0.223154 & $7,056.60$ \\
\hline Dhanlaxmi Bank & 341.57 & 11438.18 & 0.133153 & 760.00 \\
\hline
\end{tabular}

\section{LRMES calculations for Post-COVID}

\begin{tabular}{|l|l|l|}
\hline Public Bank Feb 2021 & \multicolumn{3}{|l|}{} \\
\hline & Beta & LRMES \\
\hline SBI & 1.2 & 0.2337 \\
\hline PNB & 0.73 & 0.1495 \\
\hline Bank of Baroda & 1.01 & 0.2007 \\
\hline Canara Bank & 1.25 & 0.2422 \\
\hline
\end{tabular}

\begin{tabular}{|l|l|l|}
\hline \multicolumn{3}{|l|}{ Public Bank Feb 2021 } \\
\hline & Beta & LRMES \\
\hline HDFC Bank & 1.1 & 0.2165 \\
\hline ICICI Bank & 1.46 & 0.2767 \\
\hline Kotak Mahindra & 1.1 & 0.2165 \\
\hline Axis Bank & 1.59 & 0.2972 \\
\hline
\end{tabular}




\begin{tabular}{|l|l|l|}
\hline Union Bank & 0.76 & 0.1552 \\
\hline Bank of India & 0.73 & 0.1495 \\
\hline IOB & 0.54 & 0.1129 \\
\hline Indian Bank & 1 & 0.1990 \\
\hline UCO Bank & 0.42 & 0.0890 \\
\hline Bank of Maharashtra & 0.54 & 0.1129 \\
\hline Central Bank & 0.49 & 0.1030 \\
\hline Punjab \& Sind & 0.71 & 0.1457 \\
\hline
\end{tabular}

\begin{tabular}{|l|l|l|}
\hline IndusInd Bank & 1.69 & 0.3127 \\
\hline Bandhan Bank & 1.54 & 0.2894 \\
\hline Yes Bank & -0.2 & -0.0454 \\
\hline AU Small Finance & 0.91 & 0.1828 \\
\hline IDBI Bank & 0.94 & 0.1882 \\
\hline IDFC First Bank & 1.21 & 0.2354 \\
\hline Federal Bank & 1.4 & 0.2670 \\
\hline RBL Bank & 1.34 & 0.2572 \\
\hline City Union Bank & 1.04 & 0.2060 \\
\hline Equitas Bank & 0.97 & 0.1936 \\
\hline Karur Vysya & 0.79 & 0.1608 \\
\hline DCB Bank & 0.86 & 0.1737 \\
\hline JK Bank & 0.86 & 0.1737 \\
\hline Karnataka Bank & 0.86 & 0.1737 \\
\hline South Ind Bk & 0.81 & 0.1645 \\
\hline Dhanlaxmi Bank & 0.79 & 0.1608 \\
\hline
\end{tabular}

LRMES calculations for Pre-COVID

Appendix D

\begin{tabular}{|l|l|l|}
\hline \multicolumn{4}{|l|}{ Public Bank Feb 2020 } & Beta & LRMES \\
\hline SBI & 1.74 & 0.3201 \\
\hline PNB & 1.75 & 0.3213 \\
\hline Bank of Baroda & 1.74 & 0.3195 \\
\hline Canara Bank & 1.91 & 0.3455 \\
\hline Union Bank & 1.91 & 0.3459 \\
\hline Bank of India & 1.94 & 0.3491 \\
\hline IOB & 0.79 & 0.1602 \\
\hline Indian Bank & 1.47 & 0.2782 \\
\hline UCO Bank & 1.01 & 0.1999 \\
\hline Bank of Maharashtra & 1.15 & 0.2256 \\
\hline Central Bank & 1.09 & 0.2147 \\
\hline Punjab \& Sind & 1.12 & 0.2199 \\
\hline
\end{tabular}

\begin{tabular}{|l|l|l|}
\hline Private Bank Feb 2020 & Beta & LRMES \\
\hline HDFC Bank & 1.01 & 0.2013 \\
\hline ICICI Bank & 1.38 & 0.2634 \\
\hline Kotak Mahindra & 0.94 & 0.1878 \\
\hline Axis Bank & 1.28 & 0.2471 \\
\hline IndusInd Bank & 1.65 & 0.3058 \\
\hline Bandhan Bank & 1.28 & 0.2476 \\
\hline Yes Bank & 1.96 & 0.3524 \\
\hline AU Small Finance & 0.60 & 0.1237 \\
\hline IDBI Bank & 1.43 & 0.2719 \\
\hline IDFC First Bank & 1.31 & 0.2519 \\
\hline Federal Bank & 1.47 & 0.2782 \\
\hline RBL Bank & 2.05 & 0.3655 \\
\hline City Union Bank & 0.55 & 0.1157 \\
\hline Equitas Bank & 1.42 & 0.2695 \\
\hline Karur Vysya & 0.98 & 0.1946 \\
\hline DCB Bank & 0.94 & 0.1881 \\
\hline JK Bank & 0.95 & 0.1903 \\
\hline Karnataka Bank & 1.26 & 0.2433 \\
\hline South Ind Bk & 1.14 & 0.2232 \\
\hline Dhanlaxmi Bank & 0.64 & 0.1332 \\
\hline
\end{tabular}

